が，本研究であ15〜25時間頃がピークのようである。ま た Jamarin 等は 9 日間の絶食では腺細胞 の形態的損 失, 空胞化を述へで拈り, 本研究では殊に著明に減少し た48時間の細胞には大小不同の透明な空胞が腺腔側に多 数見られた。

\section{6. 弗化物塗布によるう蝕予防の臨床的実験の研究}

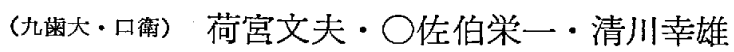
一田尚利・ 前田義信・小林 力

う蝕予防法としての弗化物局所塗布は，従来上り $2 \%$ 弗化ソーダ (NaF) の年 4 回塗布が行なわれているが, 近年 $8 \%$ 弗化錫溶液 $\left(\mathrm{SnF}_{2}\right)$, 酸性弗素燐酸溶液 $(\mathrm{NaF}$ $\left.-\mathrm{H}_{8} \mathrm{PO}_{4}\right)$ の年 1 回染布法が， より顕著な効果を有して いるという報告がみられるが，まだ一定の成績を得てい ないようである。それでわれわれは，二つの小学校の 8 才坚を対象として，それぞれに８％弗化錫溶液（南小 倉)，酸性弗素燐酸溶液（日明）を塗布した。1967年 6 月に第 1 回目の口腔診查並びに弗化物の塗布を行ない, 1968年 7 月に第 2 回目の口腔診查行なって, 1 力年間の 観察を行なった．観察項目は（1）第 1 回目口腔診査時 永久歯生歯数，（2）第 2 回目口腔診査時永久歯生雪数 （3） 1 年間の増加歯数 $[(2)-(1)]$ （4）第 1 回目 口腔診査時 DMFT 数, (5) 第II回口腔診查時 (1) の DMFT 数, (6) 第开回目口腔診查時 (2) のDM FT 数, (7) 1 年間の増加 DMFT 数 $[(5)-(4)]$, (8) 第 1 回目口腔診查時 FT 数, (9) 第 回 (5) の DMFT 数中 FT 数. (10) 第II回 (6) の DMFT 数中の FT 数である. これより第 1 回目口腔診查時の DMFT 率 $[(4) /(1)]$, 第II回目口腔診查時の DM FT 率 $[(5) /(1)]$, 第 II 回目口腔診査時の DMFT 率 $[(6) /(2)], 1$ 年間増加 DMFT率 $[(6)-(5) /$ (3)]を算出し，第吕回目之第I回目 DMFT 率の差 $[(5 /(1)-(4) /(1)]$ の検定を行なった. 以上の成 績上り見て, 日明小学校と比べて南小倉小学校の方が DMFT 数の増加が目立ち, 従って DMFT 率の差も 大きい. な找回は弗化物塗布を行なっていない対象群 との比較は例数の関係で発表していない，両弗化物のう 蝕予防効果の比較については今後研究を続け，報告した いと思う.

\section{7.霜みがき他と歯ならびに歯肉の健康との関係} (九哨大・簿) 村 岡 俊 彦

1. 研究目的

歯肉健否（歯肉炎，歯槽膿漏，健康な屯の）う歯扣よ び melanin 色素沈着と食物との関係について調查した。

2. 対 象
北九州市内の中・高校生12～18才の男女1364人

3. 観察項目

歯肉の健康なもの，歯肉炎，歯槽膿漏，う歯数, melanin 色素沈着, 歯石沈着, Stippling 执よび咬合不正 などを調查した，温度の高いもの，熱い食物，硬い食 物, 軟い食物甘, 味の食物, 辛味の食物, 肉類, 魚類, 野菜, 酸性アルカリ食品などについてそれらを好むか否 かを筆答により答えさせた。

4. 成績と結果

1）茵肉之食物との関係

歯肉の健康なむの，歯肉炎，および歯槽膿漏のに温度 の高いもの，硬い食物，軟い食物，甘味の食物，辛い食 物, 肉類, 野菜, 魚類, 酸性食品, アルカリ食品のいず れあすきなむのが多い，歯肉炎之膿漏に熱い食物のすき なものが多く，膿漏に Stippling 十のむのが多い，また melanin 色素沈着十および歯石沈着十のものが膿漏に多 w.

2）う歯数と食物との関係

温度の高い，甘味，酸性およびアルカリ食品のすきな ものにう歯数が多い.

3）酸性，アルカリ食品のすきなものに melanin 色 素沈着が多い.

\section{Tetracycline 系薬剤が乳歯におよぼす影響とくに 着色歯の營光顕微鏡観察}

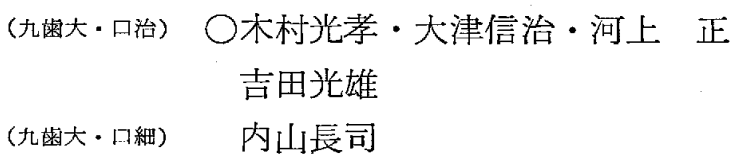

日常の臨床でしばしば歯牙の着色をみることがある。 今回わた七たちは，本学保存部小児歯科外来患者につい て，肉眼的にみてテトラサイクリン系抗生物質使用によ る副作用としてあらわれたと思われる歯牙着色の症例に 遭遇したので，䛦療録により抗生物質投与状況をできる だけくわしく調查した。その蛍光顕微鏡学的観察を報告 する．観察にあたっては，テトラサイクリン蛍光帯を有 すると思われる乳歯抜去歯牙を脱灰するととなく研磨切 片標本を作製し，オリンパスの日本光学蛍光顕微鏡装置 で観察を行なった。倍率は100倍，光源は US の10, フ ィルターは DV の1，コンデンサーは暗視野コンデン サーを使用し，30秒の露出で撮影を終了した．観察した 範囲は歯冠部，歯頸部，歯根部の 3 つの部位に分けて, 正常な崡牙と比較しながら，同一部位を観察した，正常 な歯牙については，自家蛍光むほとんど認められなかっ た．着色歯牙にいつては，エナメル質では蛍光帯は認め られず，象牙質に限局して認められた。蛍光線条は象牙 
質の成長発育線に沿ってエナメル質象牙質の境界部でき わぬて明瞭に観察された。 蛍光線 条の終末部は象 牙質 で非蛍光性となって現われている，蛍光線条の大きさ (幅), 明るさ (明暗度), については, 薬剤の投与量に 関係があるか, 薬剤を中止したためか, また循環器系に よるあのか今後の大きな問題点であり，現在動物実験を 行なっているので，その他については次の機会に報告す る:

\section{9. 著明なる橉根壪曲の 1 例}

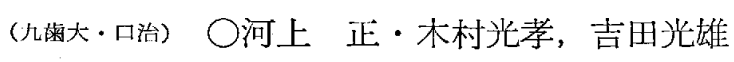
最近，私共は，上下顎，左右側 8 本の小曰歯蒾根が特 異的に彎曲した珍らしい症例に遭遇したので, その概要 を報告する．

本症例の患者は腎臓，心臟に疾患があり，さらに胃晹 障害屯伴って, 現在某病院にて加療中の32才の女性であ る. 口腔内所見：清掃状態は普通で，歯石，之の他の沈 着物, 軟組織部の発赤, 腫脹などは認められない. 各歯 牙の歯冠部の発育形態は概して正常であるが，やや上䫇 前突気味の咬合状態を呈す。本患者は出生時, 未熟児で あり，8〜9頃才熱性疾患に罹患したとのことである。 なお，患者の6才になる女の子は脳性小児麻瘏患者であ り，上下顎の全乳歯はエナメル減形成を呈している.

小曰蔝歯根のレントゲン的所見

14 : 歯根全体が $\mathrm{S}$ 字状の彎曲をなし，歯根中央辺まで の凸彎は近心側に，菡根中 央以下 は遠心側に向いてい る.

15：歯根中央辺を軸とした「逆く」の字状屈曲を示 し，その屈曲は近心側に向いている。

$\sqrt{4}$ : 上顎のあのとやや異なり，根尖 $1 / 3$ 辺から近心側に 屈曲している.

可：上顎のものと似た「逆く」の字状屈曲を呈す。

41: 歯根中央辺より根端が近心方向に約 $45^{\circ}$ の屈曲を なし,さらに根尖が, わずかに遠心側に彎曲している。

$\underline{5}$ |: 4 纪似ている.

$\overline{4} \mid$ : 根尖部がやや尖鋭化し，わずかに近心側に彎曲 している.

51：歯根中央辺より根端が近心方向に約 $45^{\circ}$ の屈曲を なし，かつその屈曲根は軽度の彎曲を呈している。

以上 8 歯の歯冠長に対する歯根の長さおよび歯冠の近 遠心的幅径に対する歯根の近遠心的幅径の割合関係は, ほぼ正常に近い，また，それら周团の歯槽骨の構築関係 も正常のようである. 歯根彎曲の一般的原因としては外 傷, 顎骨の発育不全, クル病, 梅毒, 栄養障害などがあ
げられている，本症例の場合は，上記のごとく熱性疾患 に罹患した 8〜9才頃は, 該雨橉根形成の開始時期に相 当するのであるから，多分にそれによる影響む一因した ことだろうと考える。

\section{0. 固体の比熱測定法特に混合測定法の改良測定法につ いて}

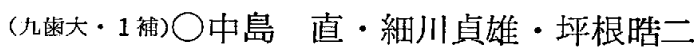
(九工大・機械) 宮部喜代二・勝原哲治

固体の比熱測定には一般に混合法が知られている。混 合法では, 試料投入による断熱容器中の液体の温度変化 を正確に測定する事, 水当量を含む熱量損失を正確に知 る事により测定精度が高められる。しかし, 少量の試料 を用いた場合，測定精度を高めることは，大変困難なと とである。

ここに示す改良混合法は基本的な考えは，すでに発表 された二二の方法と同様であるが, 特長として, 少量の 試料の場合でも簡単な装置, 操作により, かなりの精度 を期待できる点にある，私達は人間歯及び㐘科材料の熱 的性質を解明するに当って，形状が小さく不定形の試料 の熱的性質を測定するには，直接熱伝導率を求める事は きわめて困難ですので，比較測定法などにより先ず温度 伝導率を求め, ついで比熱, 比重を測定し, 熱伝導率を 算定する力法が商当と考えた。本法は, 混合法のもつ欠 点を除き，試料が少量で且つ投入により生ずる温度差が 小さくてもかなりの精度で比熱が求められる。

改良混合法に上る比熱測定には，市販 銅材，高溶陶 材, ガラス陶歯, アクロン， 1 年以上経過した报去歯牙 を試料とした。

実験開始前に試料の重さを測定し, 次に2コのジュア ーびんに等温, 等量の水を入れ断熱箱中に設定する. 直 ちに両容器の温度差の記録を始め, 適当な時間経過後, 一万の容器に試料を投入し, 直ちにゴム栓を閉る。この 操作を早く行なわぬと, 記録曲線に乱れが生ずるので注 意を要する。投入前の試料は安定した大気中に放置し, その大気温度を試料の初期温度 $\mathrm{tx}$ として熱電対により 同時に測定記録するようにしてある. 温度測定には何れ あ検定ずみの0.3 $\mathrm{mm}$ 径の銅ーコンスタンタン 素線 熱電 対を用いている.

本実験は混合法を改良し，外部への熱量損失を考虑す るととなく，比熱測定ができる方法である，また陚料が 少量であ, 高い精度で且つ簡単な装置を用いて測定でき る特長がある測定精度は土3\%以下と推定される。 